\title{
Policy Transfer of Branding and Reputation Management: Motivations, Challenges, and Opportunities for a Small Rural Municipality
}

\section{Public Performance and Management Review}

Abstract:

This paper seeks to convey a broader understanding of policy transfers between different sectors, focusing on transfers from the for-profit sector to local government. Specifically, we study the reasoning in a transfer process of branding and reputation management policy. Our case is a rural Norwegian municipality struggling to combat depopulation. This study is longitudinal. We discover that some original program elements cannot easily be transferred to the democratic context of local government. The transfer involves both interpretations and adjustments of the policy because of municipal institutional characteristics and values. The success of transfer depends here on the ability to balance the original policy with practices widely valued within the new setting.

Keywords: policy transfer, public sector, municipality, branding, reputation management

Word count: 8959 words, including reference list.

Åshild Skjegstad Lockert (Corresponding author), Department of Social Sciences, UiT - The Arctic University of Norway.

Hansine Hansens veg 18, 9019 Tromsø, Norway

E-mail: ashild.s.lockert@uit.no, Phone: +4798821737

Hilde Bjørnå, Department of Social Sciences, UiT - The Arctic University of Norway.

Hansine Hansens veg 18, 9019 Tromsø, Norway

E-mail: hilde.bjorna@uit.no, Phone: +4777644338

Martin Sollund Krane, Department of Social Sciences, UiT - The Arctic University of Norway.

Hansine Hansens veg 18, 9019 Tromsø, Norway ${ }^{1}$

E-mail: mkra@norceresearch.no, Phone: +4790567744

\footnotetext{
${ }^{1}$ From august $1^{\text {st }} 2018$ Martin Sollund Krane works as a researcher at NORCE Norwegian Research Centre, Sykehusvn. 21, 9019 Troms $\emptyset$, Norway
} 


\section{Introduction}

Policymakers in all sorts of organizations are usually looking to each other when reforming; they tend to transfer known policies from other organizations to their own, and have increasingly come to rely upon policy transfers (Dolowitz \& Marsh, 2000). A policy transfer is a "process in which knowledge about policies, administrative arrangements, institutions etc. in one time and/or place is used in the development of policies, administrative arrangements and institutions in another time and/or place" (Dolowitz \& Marsh, 1996, p. 344). It is a phenomenon unrestricted to policy fields, society levels and domains; a policy may well be transferred from organizations with completely different characteristics than those of the "transferring entity." Consequently, institutions like municipalities might well attempt such long transfers of policies and administrative arrangements by looking to organizations with fundamentally different agendas, motivations, and resources.

This article focuses on long transfers to municipalities. Municipalities in Scandinavia have a plethora of tasks and responsibilities, and, because they are democracies, they rely heavily on public support. They are constantly subjected to policy reform ideas. Scandinavian municipalities are, however, quite autonomous, that is, they are in many instances free to consider, develop and decide about policies to be implemented. This freedom implies they can choose to transfer policies either from other municipalities or from other organizations, both public or private. To a large extent, they choose to transfer policies from private organizations. One of the more recent popular reform ideas is branding and reputation management (BRM): A novel idea about the benefits of being remarkable, known and admired. The "BRM policy" does, however, stem from the private, for-profit sector, that is, it originates in a completely different domain where big international companies with vast 
resources and extensive managerial capacity set the agenda. Nonetheless, even very small municipalities in Norway are eager to transfer BRM policies, despite what some scholars argue, namely that BRM, associated originally with central leadership agendas and top-down directives aiming to carve out and cultivate a unified brand, is virtually incompatible with democratic forms of government (Byrkjeflot, 2015; Riezboz, 2007). BRM in the for-profit sector is traditionally known for top management decision making and consistent and strategic communication. Local governments, however, are typically characterized by a bottom-up approach to decision making, by disagreement between democratically elected politicians, and by a comprehensive set of assignments and considerations. Given the many differences, one would expect such lengthy transfer attempts to fail or result in a complicated process that triggers merely minor changes in everyday municipal practices.

This article seeks to convey a broader understanding of policy transfers between very different policy domains. While the policy transfer literature and the BRM literature offer rich insight into content and outcomes, the specific motivations, degrees of transfer and indepth understanding of practices in long policy transfers remain largely unexplored. This neglect is problematic, because it allows neither scholars nor practitioners to sufficiently understand how certain desirable results are achieved. To investigate a long policy transfer, this article focuses on the transferring organization's motivations, the degrees of policy transfer and how the policy transfer process can be understood. We use literature on policy transfer (Dolowitz \& Marsh, 1996, 2000; Marsh \& Sharman, 2009; Rose, 1993) to focus our analysis, and rely empirically on an in-depth case study of a very small Norwegian municipality which is strongly committed to BRM policies. 
The article offers two possible perspectives to understanding why and how policy transfers take place. On the one hand, the starting point could be dissatisfaction with something, or a political ambition, and the wish to "do something about it" (Anderson, 1978; Dolowitz \& Marsh, 2000; Polsby, 1984). These are rational explanations which hinge on efficiency regarding (material) ends, and the determination to reach these ends. On the other hand, the starting point for a policy transfer could be that the transfer and the eventual implementation in themselves enhance the social legitimacy of an organization and its members (Hall \& Taylor, 1996). In the latter perspective, the social institutionalist perspective, we find that the individual-institution relationship is built on a kind of "practical reasoning" whereby individuals, when taking action, consider institutional templates and practices widely valued within a broader cultural environment (DiMaggio \& Powell, 1991).

In the following, we first introduce the policy transfer literature and then present BRM elements from a for-profit-sector perspective. Thereafter, we describe municipal characteristics and widely accepted values in Norwegian local governments. We emphasize two local government characteristics: Their role as democracies and their different engagement in competition from that found in private firms. Next, we present our methods, the policy setting, the case municipality, and the empirical data. Finally, we discuss our findings and conclusions.

\section{Policy Transfer}

The spread of policies has been explored in several perspectives: diffusion literature (Berry \& Berry, 1999; Most \& Star, 1990; Rogers, 1995), the sociological organizational literature 
(DiMaggio \& Powell, 1991), translation theory (Czarniawska \& Joerges, 1996; Røvik, 2007), and policy transfer literature (Dolowitz \& Marsh, 1996, 2000; Marsh \& Sharman, 2009). Here, we regard reputation and brand practices in the local government sector as a new and distinct policy: We regard the reputation policy to be a high-level overall plan embracing the general goals and acceptable procedures (see Merriam-Webster 2017). A policy is regarded as "firmer" than a "travelling idea" (see Czarniawska \& Joerges, 1996; Røvik, 2007).

The critical question in the policy transfer literature is whether a successful program in one setting can be transferred to another. The starting point for a transfer might be external pressure, dissatisfaction with something, or political ambition and the wish to "do something about it" (Anderson, 1978; Dolowitz \& Marsh, 2000; Polsby, 1984). The term “policy transfer" refers to a generic framework that encompasses a range of related concepts (Stone, 1999). It captures ideas about how governments learn from others in drawing lessons (Rose, 1993), how decision makers in governments "are systematically pinching ideas" (Schneider \& Ingram, 1988), and the different paths a policy transfer can take (Rose, 1993). The policy transfer literature examines a range of questions, two of which we focus on.

First is the question of motivation: Why do organizations engage in transfer at all? According to the literature, the motivations for policy transfers vary. They can be because rational actors choose policy transfer as a response to a problem, such as efficiency regarding ends, or to dissatisfaction with the status quo (Dolowitz \& Marsh, 2000; Rose, 1991). A transfer can also occur because of outside pressure, as when political actors fear they are falling behind their peers on a popular public issue (Dolowitz \& Marsh, 1996), as 
BRM was at the time. The latter reason represents practical reasoning about how transferring BRM policies enhances the social legitimacy of the organization or its participants. In other words, agents of policy transfer, which can include organizations, networks, and individuals with utility interests and motivations, may also enhance "what is appropriate in the specific setting" and how a process "should" unfold (March \& Olsen, 1989; Selznick, 1984).

Second, processes can vary in terms of the degree of transfer. A transfer means learning from and adopting one or more selected elements of the original policy, and the borrower can choose what to borrow (Wolman, 1992). The use of knowledge from the original policy can take many forms, it may be related to institutional design, instruments or tools in use, or ideas and goals (see Bennet \& Howlett, 1992), or to strategies and tactics in other settings (Wolman \& Page, 2002).

There are mainly four different degrees of transfer. First, there is "copying," which involves enacting a more or less intact program that is already active. Copying assumes that the vast majority of institutional and contextual variables remain constant (Rose, 1993). In the real world, however, one cannot expect a program to transfer from one setting to another without culture, history, and institutions being considered (March \& Olsen, 1989; Selznick, 1984). The second degree, "adaptation," allows for some adjustments in the program and for different contextual circumstances, such as institutions and culture, to be considered. Other studies show that context is a crucial variable, influencing both the practice and outcome of new policies (Brusca \& Montesinos, 2016). The third degree, "combination,"2 involves

\footnotetext{
${ }^{2}$ Here, we have narrowed it down to four categories. We combine Rose's (1991) "synthesis" and "hybrid," which we label "combination" in line with Dolowitz and Marsh (2000).
} 
mixtures of elements from two or more programs; if parts of the prior settings are very different, elements may have to be borrowed from other programs. Fourth, there is "inspiration," which involves "using programs elsewhere as an intellectual stimulus to develop a novel program" (Rose, 1993). "Inspiration" suggests that policies in other jurisdictions can inspire new policy. It can involve the transfer of "policy labels" or names applied to a wide range of policies to reflect ambiguous and loosely bundled ideas (Mossberger, 2000; Wolman \& Page, 2002).

\section{BRM in the for-profit sector}

The reputation management literature regards a favorable reputation as an asset. Fombrun (1996, p. 37) defines reputation as "the overall estimation in which a company is held by its constituents." Reputation management builds on the notion that every firm has a reputation that should and can be managed (Doorley \& Garcia, 2011) and that reputation, if properly managed, will improve the firm's competitive ability and increase profits (Fombrun, 1996; Fombrun \& van Riel, 2004). For-profit firms therefore follow reputation strategies to obtain competitive advantages in attracting applicants for jobs, investors and customers, to establish themselves internationally, to out-compete local rivals, to access the resources they need, to increase profitability, and to reduce firm costs (Deephouse, 2000; Gibson, Gonzales, \& Castanon, 2006; van Riel \& Fombrun, 2007; Walker, 2010). Competition is also a core element in the corporate marketing literature, with a strong focus on product branding (Olins, 2002). ${ }^{3}$ Perhaps the most commonly cited definition of a brand in branding literature

\footnotetext{
${ }^{3}$ Nowadays, corporate branding literature includes not only products but also the marketing of the organization itself (Byrkjeflot, 2011).
} 
is a "name, term, sign, symbol, or design, or a combination of them intended to identify the goods and services of one seller or group of sellers and to differentiate them from those of competition" (Kotler, 1991). In corporate branding literature, core values are understood to be "the guiding principles for all internal and external brand building processes" (Urde, 2003, p. 1035).

The essential messages of the reputation management in the for-profit sector and corporate marketing literature, the BRM "philosophy," so to speak, are thus similar: BRM has to do with standing out from competitors, and the existence of distinct targets and consistent policies. The most common BRM policy elements used for achieving a good reputation are to pinpoint core values and unique corporate identities (Harris \& Chernatony, 2001), to communicate those core values and identities clearly and consistently over time, and to stand out with unique qualities. Formulating new reputation strategies involves strategic thinking and is primarily an expression of senior managers' goals and their views on what the organization aspires to be (Collins \& Porras, 1994; Fombrun \& van Riel, 2004). We consider "competition," "distinct core values," and "a unique identity" to be the core BRM policy elements in the for-profit sector.

\section{BRM in public institutions and Norwegian local democracy values}

Reputation management is increasingly popular in the public sector. On one hand, we find that public sector reputation literature argues that the BRM philosophy is a powerful "idea" implemented in the public sector because it provides acceptance and legitimacy (see Byrkjeflot, 2015; Solbakk, 2014; Røvik, 2007, 2011). Public organizations must address public expectations, political accountability, clarity of goals, and priorities (see Ryan, 2007). 
The organizational culture dimension of BRM management in the public sector is critical in developing stakeholder trust, which is developed through customer service, vision and leadership, emotional appeal, the service offered, and corporate governance (Ryan, 2007). Scholars within this tradition have also highlighted an inherent tension between BRM and the democratic values and bureaucratic principles in the public sector (see Byrkjeflot, 2015; Wæraas, 2008; Salomonsen and Nielsen, 2015). For example, BRM policies are commonly said to require strong, centralized leadership in order to construct and convey a uni-vocal brand image, something which is lacking in the case of democratic-led government bodies. In a local government, a polyphony of different voices participates (Riezbos, 2007).

On the other hand, we find literature that argues that BRM policies are introduced in the public sector because they provide efficiency regarding valued ends, and that how they are played out is influenced by actors' interests and motives (Bjørnå, 2016; Carpenter, 2010; Maor, 2015). In this strand of literature, reputation is regarded as a "valuable political asset" that can be used to generate autonomy, discretion from politicians, and to recruit valued employees (Carpenter, 2002, p. 491).

For a local government in Norway, it is important to achieve both economic development and stakeholder trust. All 422 municipalities (2018) have the same duties and responsibilities, regardless of size. They oversee much of the welfare provision on behalf of the state and have the autonomy to take development initiatives. Norwegian municipalities have several characteristics that make them likely to have different reasoning than does the for-profit sector in their BRM policies. We will emphasize two. 
First, municipalities are local democracies, meaning that both the political parties and citizens contribute to setting the directions for policies. The local democratic value, including broad participation, is fundamentally important for the legitimacy of the municipality (Bjørnå, 2014; Rose, 2005). The municipal leadership must simultaneously balance a multitude of (sometimes) conflicting values, goals, considerations, and stakeholder interests (Christensen, Lægreid, Roness, \& Røvik, 2009). At the same time, however, we find that municipal leadership is likely to be motivated by political ambitions and reelection. The ability to find solutions through innovative and carefully considered strategies in areas such as economic development is essential for a political party to succeed and might well be one of the driving forces (see Polsby, 1984).

Second, municipalities engage in a different form of competition than do private firms. They compete for skilled employees, and the smaller ones want to attract new residents to uphold viable population numbers (Bjørnå \& Aarsæther, 2009), but they do not compete for profits in the free market. In parts of economic literature, municipalities are expected to be tuned to competition with other municipalities to achieve development and growth (Molotch, 1976); given mobile "consumer voters" and sufficient variation between municipalities, people will move to the municipality that best represents their needs and preferences; hence, localities constantly compete for inhabitants (Tiebout, 1956). Norwegian municipalities are, however, financed in a system that aims to provide equitable conditions in all municipalities, and the smaller municipalities depend on cooperation with neighboring municipalities to provide some services. However, branding and cooperation can conflict with one another. Branding is characterized by maintaining uniqueness and brand distinctiveness, whereas collaboration is guided by norms of reciprocity and mutuality (Tschirhart, Christensen, \& Perry, 2005). In 
Norway, the maintenance of cooperative relations with nearby municipalities (especially in rural areas) is an important value, and one likely to be just as important as the eagerness to compete (see Wæraas, 2015). ${ }^{4}$

The democratic nature of municipalities and their mildly tuned competition would expectedly make it very difficult for actors in municipalities to do a full copy of the forprofit-sector BRM policy in transfers.

\section{Methods}

Studies of policy transfers are often empirical, focusing on, for example, social policy, public education, urban planning (Benson \& Jordan, 2012), and transport policy (Marsden \& Stead, 2011). The literature tends to focus on questions such as: Who transfers policy? Why? What policy elements are transferred? Are there different degrees of transfer? We have narrowed the focus to the motivation for transferring, the "degree" of transfer, and how the process can be understood with regards to rational or practical reasoning. We study a "long" transfer: from a policy domain associated with the supranational level to a local policy domain; from a resource-rich to a less resource-rich domain; from a domain emphasizing profits to one emphasizing several other important values. We hypothesize that such transfers will likely fail or result in only minor changes in the municipality's everyday practices.

We choose a small Norwegian municipality as our case on the grounds that it is very

\footnotetext{
${ }^{4}$ A Norwegian survey shows that a clear majority of municipality officials do not want to use differentiating techniques to achieve competitive advantages (Wæraas, 2015).
} 
different from international companies associated with the "original" BRM idea. Hence, we expect the transfer to be especially challenging. The municipality is small, with fewer than 1600 inhabitants, rural, and with no previous knowledge of BRM. Our case municipality was one of only two municipalities in Norway in which officials have attended both BRM learning programs hosted by government agencies. In line with Yin (2014), we expected this case to yield the best data from a transfer process due to its uniqueness, both in terms of organizational characteristics and the commitment to learning and implementing BRM.

We used a longitudinal approach together with the triangulation of methods and sources to capture rich, in-depth data over time, allowing us to study the phenomenon in its real-life context (Yin, 2014) and to describe "why" and "how" things unfold (Miles, Huberman, \& Saldana, 1994). We conducted repeated semi-structured interviews with mayors, public administrators, and stakeholders (Court, 2012), we reviewed local media coverage, and we studied ministry and municipal reports and documents (reputation policy was addressed in several council meetings). We also attended two separate sessions of a governmentfacilitated BRM learning school for municipalities (in 2012 and 2013). Here, we made observations, interviewed the case municipality's delegation and program managers, and we read program literature.

\section{Table 1: Overview of empirical data sources: Interviews}

In 2016, we visited the municipality and conducted our interviews in city hall, focusing on the informants' reflections on the various actions taken in the BRM transfer process. Over the years of the study, we asked informants whether they were aware of the competitive element in BRM, if they adjusted the municipality's BRM process to it, and we encouraged them to reflect upon the implications of competitiveness for regional relations. We asked 
them whether they thought the municipality had some special values distinguishing it from other municipalities and, if not, how they would establish such values. We asked straightforwardly if the municipality had a common identity and whether the goal was to develop one.

We transcribed the recordings and reflected upon the sincerity of answers and the influence of external factors (Richards, 2005, p. 51). Informants seemed sincere, but we were aware that interviewees might want to present their stories favorably because a positive appearance is important for actors involved in BRM. This might be seen as an inherent methodological challenge in studying BRM polices, and although we kept this in in mind while interpreting the interviews, we are aware that there can be no guarantee that this methodological challenge could not limit the validity of our study's findings.

The municipal BRM process's course, studies of ministry and municipal reports, scrutiny of the BRM school's program literature, and reviews of local media coverage all informed our understanding of the degree of policy transfer. According to BRM philosophy, the most common elements used for achieving a good reputation are to pinpoint core values and to emphasize unique qualities. Here, our understanding of the degree of "copying" is thus that the elements competition, core values, and the forging and signaling of a unique municipal identity would be essential to the municipal BRM process. The degree of "adaptation" would mean adjustments regarding these elements and that institutional context and culture are considered, while "combination" would imply mixing elements from two or more programs. The BRM schools were a somewhat different proponent of this policy, and we aimed to find the effects of both the schools and the BRM philosophy on the transfer process. Fourth, we understand "inspiration" as the use of ideas and concepts from programs elsewhere to 
develop a novel program.

In the following two sections, we introduce the BRM policy setting, the case municipality, and the case transfer process.

\section{The BRM policy setting}

"Municipality branding" is a rather new policy concept in Norway. The previous minister in charge of local and regional affairs was one of the principal initiators for promoting BRM as a policy in municipalities. She had spoken together with young rural residents and asked them what would make them more likely to return to their home municipality after completing their education. "A better municipal reputation" was typically part of the answer. At that time (around 2006), "reputation" was very much a buzzword in the Norwegian media and loomed large as a popular trend, even among researchers (Kornberger, 2010; Røvik, 2007; Wæraas, Byrkjeflot, \& Angell, 2011). In fact, The Association of Norwegian Municipalities (KS) highlighted reputation in its 2007 employer strategy (KS, 2007). The Norwegian Ministry of Local and Regional Affairs established an agency called the Reputation School (RS) in 2008 to promote learning in the municipalities about reputation management, and some years later the minister launched an additional learning program, involving labor unions and KS. This program was called Together for a Better Municipality (TBM) and focused on, among other things, municipal reputation management. The schools are facilitators of BRM policy transfer from the for-profit sector to the public municipal sector, and our case municipality attended both.

\section{The case municipality's approach to BRM policies}

The case municipality is rural, located in the inland mountain area, with less than 1600 inhabitants (Statistics Norway, 2018). In the past, the main commercial activity was closely 
linked to mining in other parts of the region, but the mines are now closed. The municipal administration is the main local employer. The municipality also has many farms, especially eco farms, accounting for about $25 \%$ of the workforce. Like councils in other rural municipalities, it is very concerned about sustainability and population decline. According to the CEO, the relatively strong position of agriculture helps the population "stay somewhat stable" (CEO, 2016), and the municipality has taken steps to stem population decline. In the following we present how BRM is addressed.

\section{The motivation for implementing BRM policies}

Surprisingly, according to the mayor, "the municipality has never had a bad reputation" (Mayor, 2016), so the motivation behind engaging in BRM never sprang from a need to fix a negative reputation. However, as a small, rural municipality, depopulation is regarded as the main challenge. One strategy to attract new residents has been advertisements for new residents from the Netherlands. This strategy worked fairly well, according to our sources, but depopulation remains a challenge. The other main strategy has been to implement BRM policies. According to informants and the municipal website (Dec. 2012), participants from the municipality attended BRM learning schools to learn to use branding as a tool, with the overarching aim to make the municipality a more attractive place to work and live.

Major actors in the municipal leadership wanted to learn more about how to attract new residents and searched for ideas in learning programs for the municipal sector. The neighboring municipal leadership had the same thought, and both municipalities applied to and were accepted by the TBM program. The TBM program focused on internal processes in the municipality and gave the CEO a prominent role. CEOs from both municipalities 
attended several program gatherings, where they worked on social work, technical services, agriculture, sport, and common leadership projects that the municipalities could undertake together: "This should make us [both municipalities] better on services and provide services that are perceived positively among users" (Mayor, 2013).

On the initiative of the leadership in the neighboring municipality, both municipalities then also registered for the RS. Decision makers in the case municipality had not previously been explicitly concerned with ideas of branding or reputation, but "we were interested in this sort of work," said the CEO in 2016. In addition, the mayor explained, the RS seemed to offer an interesting approach to the imminent revision of the municipal strategic plan.

The case municipality's leadership came to actively pursue the reputation policy. In the second RS learning session, the CEO, mayor, head of the development unit, and a politician attended from the municipality. BRM policy appealed to both the CEO and the mayor. Before they started working on BRM, they wanted to draw lessons from the RS, and the RS clearly inspired the municipal leadership: "It gave us some tools [to work with]; we were made aware of our qualities and how to work" (CEO, 2012). Branding strategies became one of two main pillars in revising the municipal plan.

\section{Capturing BRM policy}

Competition is an important element in for-profit BRM. In 2012, competition appealed to the CEO in the case municipality. "I have no objections to thinking of municipalities as products. We're part of a market and we compete for manpower" (CEO, 2012). In the interview in 2016, however, he expressed himself differently: "Reputation is important and 
relevant (...) but maybe the part about competition is less relevant" (CEO, 2016). The mayor also toned down the competitive element in BRM policies in 2016:

We don't compete with other municipalities; we are more complementing each other (...) We are not trying to conquer each other's position in the region. (...) We are not just a [standalone] municipality - we are part of a larger region, and this branding and reputation strategy must fit into a bigger regional picture (Mayor, 2016).

The head of planning and engineering thinks that it is possible to both compete with and complement the different municipalities in the region: "We're part of a broader setting (...) (we should) both compete for citizens, but also complement each other" (Head of Planning and Engineering, 2016).

The case municipality's distinct core values were initially unclear, and the process toward finding them became long and complicated. Council politicians were less involved when the school learning program was being followed, but the council approved the reputation policy projects. They eventually got involved in BRM work and discussed different tasks (like immigration, employment, and housing) and what they considered relevant subjects for branding policy. There were simultaneously many groups brainstorming and working on reputation and branding. "It was quite a mess," said the mayor in 2016 when recalling the process.

At this stage, the case municipality and the neighbor municipality were thoroughly cooperating on BRM policy. An internal common steering group for the two neighboring municipalities consisted of members from the municipal organizations (council officers, the CEO, and politicians, including the mayor). This group was led by a project manager hired 
in a $30 \%$ position and who had the overriding responsibility. In addition, both municipalities established "external groups." The case municipality included people from the business community and civil society in addition to two politicians in its external group. The external group reported to the superior group and worked explicitly on a " 10 -item list" provided by the RS learning school program and developed suggestions in an official presentation distributed on the municipal website. On a slide focusing on the municipality's core values, the old slogan "X has got guts" stood out. The external group's main suggestion was to keep this slogan. The presentation also highlighted the municipality's relation to food and culture, as well as the values honesty and authenticity, both in terms of how the municipality traditionally presented itself and in how food and traditions were culturally integrated.

The municipal leadership and council felt unready to commit to the status quo core value about "having guts." The council decided to continue the search for core values, doing so in discussions of other municipal projects: they discussed core values in sports, business and tourism projects, and in strategies for cooperation with the neighboring municipality. The chief municipal medical officer, for instance, suggested that the reputation policy should advance public health. "The policy will find its direction, and we are bound to get more elements involved in it," as the mayor explained in 2013.

The council then decided to include citizens in discussions about core values. It arranged public meetings where it solicited ideas for core values. At the public meetings, it became even more evident that many different interests and values existed in the municipality, such as meeting the needs of the local youth. The municipal council also had the municipal strategic plan (the societal development part) on the agenda, and they discussed reputation 
and brand policy as part of this process. Now, many stakeholders, working groups, and projects were involved in discussions about municipal core values, and numerous suggestions were considered.

However, the municipal leadership wanted development to be the prime outcome of BRM policy and continued to seek advice. They invited an expert, a PR consultant associated with RS, to help them decide, and "he inspired us" (CEO, 2012). The expert encouraged the focus on food production and values related to food production in the branding process.

The search for uniqueness overlapped the search for core values and proved to be just as difficult to determine. As the mayor said, "RS focused on being unique, but here we [municipal politicians] were convinced that it had to be authentic. Yes, unique, but more importantly, so authentic that everybody here could be an ambassador [for the municipality]" (Mayor, 2016):

It was important that the local business and the local associations didn't feel that this [uniqueness] was something they were forced to accept, something fake they didn't recognize [...] It had to be deeply anchored and based on projects and processes that were already running (Mayor, 2016).

The solution was to enlist a second PR consultant who formulated an agreed expression of what made the case municipality unique.

\footnotetext{
Although some politicians sort of resigned at this point, when someone from the outside came, we ended up with $X$ cultivates the meal $[\ldots]$ We [the politicians] were discussing something similar, but we were unable to formulate it into one short sentence. Hence, it captures much of what we discussed, and it was unanimously accepted (Mayor, 2016).
} 
The council broadly supported "X cultivates the meal," a sort of food brand, and agreed on bringing this forward in the strategic municipal plan. The mayor explains that the slogan has multiple meanings. The brand is associated with public health regarding what you eat and where your food comes from; it refers to the surroundings of a meal, "culture, traditions and music" (Mayor, 2016), and also has a literal meaning, as this is a farming municipality where food is produced: In other words, the municipality "cultivates the meal." "This [...] captures what our local community is about," says the CEO (2016). In the neighboring municipality, the slogan "activities for children and youngsters" was selected to symbolize its uniqueness. "In this way, our two municipalities will complement each other in the region" (Mayor, 2014). In 2016, the mayor said that the idea behind the food brand uniqueness is that it has the potential to be integrated into many municipal activities and other projects. The head of planning and engineering remarked: "It is difficult to choose an identity [uniqueness] on behalf of everybody" (2016). Nevertheless, she continued by stating that the uniqueness they ultimately chose was something local people recognized and identified with. The CEO (2016) agreed: "My impression is that most people involved agree." The brand "X cultivates the meal" has been integrated in the municipal strategic plan, the popular annual local festival, and in strategies for increasing tourism at local historical sites. The brand has also been integrated in the marketing of the region.

In summary, "competition" for new inhabitants was initially a core element, but the leadership toned down this element in later interviews. The regional focus and how the case municipality could complement its neighbor municipality gradually became more important. Several working groups, many discussions related to different strategic plans in the municipality, and many stakeholders were involved in the process to find core values and 
uniqueness. Not only did the municipality engage in two different learning programs, but the council and municipal leadership also took inputs from the public, stakeholder groups, and two experts. As we have seen, they ended up with "X cultivates the meal," a slogan with multiple meanings and serving to express the core values and unique identity of this municipality.

\section{Discussion}

In this article, we wanted to convey a broader understanding of policy transfers between different sectors, focusing on the lengthy process of transfers from the for-profit sector to a local government. While the case municipality had no reputation problems initially, they nevertheless engaged in BRM policies. Here, the local leadership emphasized the depopulation problem and their determination to find new ways to combat it; BRM policies were seen as a solution to target this problem, because a good reputation could motivate more people to move to the municipality (see Tiebout, 1956). Municipalities are subordinate agents executing central government policies (Hansen, 2005, p. 184), which makes them receptive to widely varied signals from central government. The minister's communication about BRM policies and the state-financed BRM schools rendered the leadership in the municipalities very receptive to brand management. We also found that BRM policies loomed large as a popular trend at the time (Kornberger, 2010; Røvik, 2007; Wæraas, Byrkjeflot, \& Angell, 2011) and, combined with their own motive, that they increased population numbers and boosted the local economy, BRM policy stood out as a very good idea.

In sum, the motivation for transferring BRM to the municipality can be seen as a 
combination of key municipal actors' rational responses to the depopulation problem and of indirect external pressure due to the policy's popularity in the media and in central government. A transfer often begins with external pressure, dissatisfaction with something, or political ambition, together with a determination to "do something about it" (Anderson, 1978; Dolowitz \& Marsh, 2000; Polsby, 1984). The incentive to transfer (BRM) programs to Norwegian local governments was a mixture of these elements.

We wanted to discover the degree to which some parts of the essence of BRM policy in the for-profit sector were transferred to the municipality. We expected the municipality to have failed or hardly transferred the policy at all due to the differences in motivation, agendas and resources, and the additional contextual differences between the policy domains. We focused on competition, finding core values, and uniqueness. Regarding competition, the municipal CEO initially had an idea that competition was a core element in the municipality's branding policies. The mayor was focused on developmental policies. However, the eagerness to compete diminished quite quickly. It became more important for the case municipality's leadership to manage a function-sharing - and to cooperate - with the neighboring municipality within the BRM policy framework. The apparent paradox between branding and collaboration (see Tschirhart et al., 2005) seems to have been downplayed in our case. The municipality brand is negotiated, integrated, and seen in relation to the marketing of the region. Rural municipalities clearly depend on one another, and a good relationship to neighboring municipalities is important. This seems to have trumped the eagerness to stand alone in a competition for new inhabitants, business development, tourists, etc.

There was an effort to find distinct core values and uniqueness. The municipality expended 
tremendous efforts on these tasks, and a complicated procedure was entered. Finding core values and uniqueness did not involve a top-down approach, but rather an approach that included broad participation, ranging from different branches of the political sector and the administration to citizens, consultants, and cooperation with the neighboring municipality. In the municipal sector, there is a strong focus on democratic participation, as this is of fundamental importance to a municipality’s legitimacy (Bjørnå, 2014; Rose, 2005). As we have seen, broad participation is not necessarily compatible with the original policy, because the original policy, with its inherent need for rigidity and consistency for success, is typically characterized by being an expression of the goals of senior management and has traditionally been found in output-oriented organizations. Bottom-up approaches and broad participation in defining and implementing a BRM policy can pose a challenge. For local governments, they might lead to multiple goals and targets and to incoherent policies. A politically led organization rarely speaks with one consistent voice, and it is claimed that clear and consistent communication is contrary to the nature of politics (Wæraas \& Byrkjeflot, 2012). The BRM process could easily have failed, as political leadership and different stakeholders had many and different interests.

However, the policy transfer did not fail. Rose (1993) discerns several degrees of a policy transfer: copy, adaptation, combination, and inspiration. The process resulted in what we consider a novel program, one too different to be seen as a copy of the original policy but too similar to be considered merely as resulting from inspiration. The food brand has become integral to many of the municipality's activities and a formal part of the municipal strategic plan, festival themes, and tourism plans, but it is not as pinpointed as first intended. Thus, we can say that the policy has had greater effect than just "inspiration" (Rose, 1993); more than 
goals, ideas, and concepts served to intellectually stimulate the transfer (Mossberger, 2000; Rose, 1993; Wolman \& Page, 2002).

The municipality's strategy addressed major elements in BRM policy: finding distinct core values and uniqueness. The strategy emphasized standalone competition less over the years, however, as this competition does not align with existing dependencies and the values of rural municipalities. The municipality's leadership aligned with a neighboring municipality and sought to compete as part of a regional platform. Furthermore, the case municipality was primarily influenced by the for-profit sector BRM elements as they were expounded in two BRM school programs. However, they did not follow point by point what was learned from BRM school programs. Nonetheless, most of the content of school programs and most forprofit BRM elements were captured in the process.

Hence, we interpret the changes made to the original policy as what Rose calls "adaptation." Involved actors adjusted the policy, accounting for their specific context, culture, and institutional circumstances. The municipal actors worked hard to integrate the policy into the population, into the municipal organization, and into existing projects. The main adjustments were made to compete as part of a regional platform and to involve multiple stakeholders in a bottom-up approach in line with the democratic nature and legitimate behavior of municipalities. An external consultant managed to combine the many suggested elements into a unified food brand, one that evoked connotations of the togetherness of a meal, the values associated with public health regarding what people eat, the culture, and traditions. One interesting empirical finding is thus that municipal leadership had to seek outside expertise to pinpoint the municipality's unique identity; stakeholders' inputs were too many 
to sort. This tells us that BRM's ideal of a uni-vocal brand became too challenging to manage in this local government because of the many voices included in the process (Riezbos, 2007).

Nonetheless, the adaptation became a success. The brand seemed to be widely accepted and can therefore be said to be appropriate and in accordance with path dependencies (see March \& Olsen, 1989; Selznick, 1984). It is highly probable that the municipality's bottom-up approach, with the inclusion of citizens and arranging of public meetings, contributed to the acceptance. The local leadership was initially interested in standing out with a good reputation to attract residents, but this interest is somewhat toned down in the actual process. Over time, there was a constant awareness and discussion of local values. We interpret the version of the BRM policy to be a sort of practical reasoning, where individuals have considered widely valued institutional practices within the broader cultural environment in their course of action (DiMaggio \& Powell, 1991). The "end product" is a local adaptation of the BRM policy and a result of multiple influences in interaction with the institutional characteristics and legitimate behavior of local government. The practical reasoning seemed necessary in order to succeed in such a lengthy transfer.

\section{Conclusion}

This article has aimed to convey a broader understanding of long policy transfers, focusing on transfers of global, private-sector policies to the public, local democratic sector. Such long transfers are quite common, but because of the differences in institutional settings, resources, and capacities, we expected that local governments would experience a complicated process, one likely to fail or result in only minor changes in the municipal 
practices. This assumption is only partly confirmed in our case study: The process was indeed complicated, it took time and vast attention. However, the long transfer proved to have extensive effects on everyday policies. It also led to reflections about traditions, history, and institutional templates and served as a legitimizing and integrative force in the community. These effects indicate that long transfers may well be successful (in the sense of leading to desired changes), but that transfer success greatly depends on the willingness to spend vast attention and resources on such transfers over time: There is no quick fix to successful policy transfers from entities with fundamentally different agendas, motivations, and resources. This is an important lesson for transferring units that consider long transfers.

Aiming at expanding the knowledge found in current literature on policy transfer and BRM, we have studied the motivation, degree of transfer, and how the process could be understood. We did so by studying the transfer of BRM policies into a small rural municipality. On motivation, we found that a combination of global trends, central government signals, and the motivation of the local leadership mattered, and had different significance over time. There was a constant awareness and discussion of local values and a practical reasoning leading to the incorporation of widely valued practices. On the one hand, for-profit BRM elements were incorporated and used to form a coherent municipal policy that is unique and consistent. On the other hand, engagement in competition was different from that found in the for-profit sector, and the search for core values and uniqueness was not top-down as in the for-profit sector. Besides the municipal leadership, many stakeholders, inhabitants, and experts were involved in defining core values/uniqueness. This is legitimate behavior of local governments and represents a necessary adaptation for a successful transfer. As to the degree of transfer, we conclude that there has been what Rose (1993) calls an "adaptation," 
meaning the original policy has been adjusted somewhat.

Thus, a theoretical finding extracted from the empirical finding is that the critical success factor for such long policy transfers is to adjust to the cultural environment at the "receiving end." The practical reasoning leading to adjustments in the original policy is necessary for the transfer's legitimacy and thereby success. Consequently, success in policy transfer requires that policies come with "soft prescripts," meaning that there are various interpretations of the paths to success. In such long transfers, there must be ample scope for transforming the original policy, and there must be ample opportunities to transform it. Our case study has shown that because of the transformable scope, the process of policy transfer became a success.

Further, this study contributes to understanding the transfer of BRM policies to local democracies. Even though BRM and democratic values have been criticized as incompatible, our case illustrates that transferring BRM policies to the public sector can be done successfully. The process can even in a sense be said to have spurred local democratic activities and contributed to a revitalization of local democratic participation in the studied municipality. Our findings show that working with this process, which included open public meetings as well as other innovative participatory elements aimed at developing uniqueness and core values, has made major actors more creative in how they implement local government policies in the strategic plan and in citizen activities. We recommend that other municipalities engaged in BRM transfers should strive for citizen participation and involvement in such processes, both to adapt the policy to their democratic context and to potentially increase democratic activities. 
In closing, we wish to mention one of the most important limitations of our study. Although informants seemed sincere in interviews, they could have been answering in a "municipalityfavorable" way. A positive appearance is important for municipal actors dealing with BRM processes. The motivations of the major actors thus represent inherent methodological challenges in studying BRM polices. Notwithstanding, we would recommend that future research examine other cases of policy transfers from the private to the public sector, focusing on the reasoning used in a democratic institutional setting in a BRM policy transfer process. Valuable inquiries could be case studies comparing transfers in various countries of for-profit-sector BRM policies to local government arenas. 


\section{References:}

Anderson, C. W. (1978). The logic of public problems: Evaluation in comparative policy research. In D. E. Ashford (Ed.), Comparing public policies: New concepts and methods (pp. 24-26). Beverly Hills, CA: Sage.

Bennett, C. J., \& Howlett, M. (1992). The lessons of learning: Reconciling theories of policy change. Policy Sciences, 25(3), 275-294.

Benson, D., \& Jordan A. (2012). Policy transfer research: Still evolving, not yet through? Political Studies Review, 10(3), 333-338.

Berry, F. C., \& Berry, W. D. (1999). Innovation and diffusion models in policy research. In P. A. Sabatier (Ed.), Theories of the public process (pp. 169-200). Boulder, CO: Westview.

Bjørnå, H. (2014). Omdømmebygging i kommunene: hva gjør de og hva vil de? Norsk statsvitenskapelig tidsskrift, 30(4), 256-276.

Bjørnå, H. (2016). Norwegian municipalities and reputation building. Scandinavian Journal of Public Administration, 20(2): 39-58.

Bjørnå, H., \& Aarsæther, N. (2009). Local government strategies and entrepreneurship. International Journal of Innovation and Regional Development, 2(1-2): 50-65.

Brusca, I., \& Montesinos, V. (2016). Implementing performance reporting in local government: A cross-countries comparison. Public Performance \& Management Review, 39(3), 506-534.

Byrkjeflot, H. (2011). Et kritisk blikk på omdømmeblikket. In A. Wæraas, H. Byrkjeflot, \& S. I. Angell (Eds.), Substans og framtreden (pp. 51-70). Oslo: Universitetsforlaget.

Byrkjeflot, H. (2015). Driving forces, critiques, and paradoxes of reputation management in public organizations. In A. Wæraas \& M. Maor (Eds.), Organizational reputation in the public sector (pp. 54-73). New York/London: Routledge.

Carpenter, D. P. (2002). Groups, the media, agency waiting costs, and FDA drug approval. American Journal of Political Science, 46(3): 490-505.

Carpenter, D. P. (2010). Reputation and power organizational image and pharmaceutical regulation at the FDA. Princeton: Princeton University Press.

Christensen, T., Lægreid, P., Roness, P. G., \& Røvik, K. A. (2009). Organisasjonsteori for offentlig sektor. Instrument, kultur, myte. Oslo: Universitetsforlaget.

Collins, J. C., \& Porras, J. I. (1994). Built to last: Successful habits of visionary companies. New York, NY: HarperBusiness.

Court, M. (2012). Longitudinal research. In A. J. Mills, G. Durepos, \& E. Wiebe (Eds.), Encyclopedia of case study research (pp. 536-539). Thousand Oaks, CA: Sage.

Czarniawska, B., \& Joerges, B. (1996). Travel of ideas. In B. Czarniawska \& G. Sevòn (Eds.). Translating organizational change (pp. 13-48). Berlin: Walter de Gruyter.

Deephouse, D. L. (2000). Media reputation as a strategic resource: An integration of mass communication and resource-based theories. Journal of Management, 26(6), 1091-1112.

DiMaggio, P., \& Powell, W. (1991). The iron cage revisited: Institutional isomorphism and collective rationality in organizational fields. In W. Powell \& P. DiMaggio (Eds.), The 
new institutionalism in organizational analysis (pp. 41-63). Chicago, IL: University of Chicago Press.

Dolowitz, D. P., \& Marsh, D. (1996). Who learns what from whom: A review of the policy transfer literature. Political Studies, 44(2), 343-357.

Dolowitz, D. P., \& Marsh, D. (2000). Learning from abroad: The role of policy transfer in contemporary policy-making. Governance, 13(1), 5-23.

Doorley, J., \& Garcia, H. F. (2011). Reputation management: The key to successful public relations and corporate communication. Abingdon: Routledge.

Fombrun, C. J. (1996). Reputation: Realizing value from the corporate image. Boston, MA: Harvard Business School Press.

Fombrun, C. J., \& van Riel, C. B. M. (2004). Fame and fortune: How successful companies build winning reputations. Upper Saddle River, NJ: Prentice Hall.

Gibson, D., Gonzales, J. L., \& Castanon, J. (2006). The importance of reputation and the role of public relations. Public Relations Quarterly, 51(3), 15-18.

Hansen, T. (2005). Kommunal autonomi: hvor stort er spillerommet? In H. Baldersheim \& L. Rose (Eds.), Det kommunale laboratorium: Teoretiske perspektiver på lokal politikk og organisering. Bergen: Fagbokforlaget.

Harris, F., \& de Chernatony, L. (2001). Corporate branding and corporate brand performance. European Journal of Marketing, 35(3/4), 441-456.

Kornberger, M. (2010). Brand society: How brands transform management and lifestyle. Cambridge, MA: Cambridge University Press.

Kotler, P. H. (1991). Marketing management: Analysis, planning, implementation, and control (7th ed.). Englewood Cliffs, NJ: Prentice-Hall.

KS (2007). Stolt og unik: Arbeidsgiverstrategi mot 2020. Oslo: Kommuneforlaget.

Maor, M. (2015). Theorizing bureaucratic reputation. In A. Wæraas \& M. Maor (Eds.), Organizational reputation in the public sector (pp. 17-36). Routledge.

March, J. G., \& Olsen, J. P. (1989). Rediscovering institutions: The organizational basis of politics. New York, NY: Free Press.

Marsden, G., \& Stead, D. (2011). Policy transfer and learning in the field of transport: A review of concepts and evidence. Transport Policy, 18(3), 492-500.

Marsh, D., \& Sharman, J. C. (2009). Policy diffusion and policy transfer. Policy Studies, 30(3), 269-288.

Merriam-Webster (2017). Policy. Retrieved from: https://www.merriamwebster.com/dictionary/policy.

Miles, M. B., Huberman, A. M., \& Saldana, J. (1994). Qualitative data analysis: A methods sourcebook (3rd ed.). Los Angeles: Sage.

Molotch, H. (1976). The city as a growth machine: Toward a political economy of place. American Journal of Sociology, 82(2), 309-332.

Mossberger, K. (2000). The politics of ideas and the spread of enterprise zones. Washington, DC: Georgetown University Press.

Most, B. A., \& Starr, H. (1990). Theoretical and logical issues in the study of international diffusion. Journal of Theoretical Politics, 2(4), 391-412. 
Olins, W. (2002). Branding the nation: The historical context. Journal of Brand Management, 9(4-5), 241-248.

Polsby, N. W. (1984). Political innovation in America: The politics of policy initiation. New Haven, CT: Yale University Press.

Richards, L. (2005). Handling qualitative data: A practical guide. London: Sage.

Riezbos, R. (2007). City branding: Sense or non-sense? White Paper of the European Institute for Brand Management. Rotterdam: European Institute for Brand Management.

Rogers, E. (1995). Diffusion of innovations. (4th. ed.). New York: Free Press.

Rose, L. (2005). Demokratiteori: forventninger og virkelighet. In H. Baldersheim \& L. Rose (Eds.), Det kommunale laboratorium. Teoretiske perspektiver på lokal politikk og organisering (pp. 53-86). Bergen: Fagbokforlaget.

Rose, R. (1991). What is lesson-drawing? Journal of Public Policy, 11(1), 3-30.

Rose, R. (1993). Lesson drawing in public policy: A guide to learning across time and space. Chatham: Chatham House.

Ryan, B. (2007). How can the corporate sector concept of 'reputation' and 'trust' be used by local government? A study to establish a model of reputation management for local government. Asia Pacific Public Relations Journal, 8, 37-75.

Røvik, K. A. (2007). Trender og translasjoner. Oslo: Universitetsforlaget.

Røvik, K. A. (2011). From fashion to virus: An alternative theory of organizations' handling of management ideas. Organization Studies, 32(5), 631-653.

Salomonsen, H., \& Nielsen, J. A. (2015). Investigating the politics of reputation management and in local government: The case of Denmark. In A. Wæraas \& M. Maor (Eds.), Organizational reputation in the public sector (pp. 203-226). New York/London: Routledge.

Schneider, A., \& Ingram, H. (1988). Systematically pinching ideas: A comparative approach to policy design. Journal of Public Policy, 8(1), 61-80.

Selznick, P. (1984). Leadership in administration: A sociological interpretation. Berkeley, CA: University of California Press.

Solbakk, M. N. (2014). Mål, utfordringer og muligheter for omdømmehåndtering $i$ offentlig sektor: Fra identitet via ekspressivitet og transparens til autokommunikasjon? (Doctoral dissertation). Retrieved from https://munin.uit.no/.

Statistics Norway (2016). http://www.ssb.no/.

Stone, D. (1999). Learning lessons and transferring policy across time, space and disciplines. Politics, 19(1), 51-59.

Tiebout, C. M. (1956). A pure theory of local expenditures. Journal of Political Economy, 64(5), 416-424.

Tschirhart, M., Christensen, R. K., \& Perry, James L. (2005). The paradox of branding and collaboration. Public Performance \& Management Review, 29(1), 67-84.

Urde, M. (2003). Core value-based corporate brand building. European Journal of Marketing, 37(7/8), 1017-1040.

Van Riel, C. B. M., \& Fombrun, C. J. (2007). Essentials of corporate communication. New 
York, NY: Routledge.

Walker, K. (2010). A systematic review of the corporate reputation literature: Definition, measurement, and theory. Corporate Reputation Review, 12(4), 357-387.

Wolman, H. (1992): Understanding cross national policy transfers: The case of Britain and the US. Governance, 5(1), 27-45.

Wolman, H., \& Page, E. (2002). Policy transfer among local governments: An informationtheory approach. Governance, 15(4), 577-501.

Wæraas, A. (2008). Can public sector organizations be coherent corporate brands? Marketing Theory, 8(2), 205-221.

Wæraas, A. (2015). Municipal reputation building in Norway: A reputation commons tragedy? In A. Wæraas \& M. Maor (Eds.), Organizational reputation in the public sector (pp. 227-243). New York, NY: Routledge.

Wæraas, A., \& Byrkjeflot, H. (2012). Public sector organizations and reputation management: Five problems. International Public Management Journal, 15(2), 186-206.

Wæraas, A., Byrkjeflot, H., \& Angell, S. I. (2011). Substans og framtreden:

Omdфmmehåndtering i offentlig sektor. Oslo: Universitetsforlaget.

Yin, R. K. (2014). Case study research. Thousand Oaks, CA: Sage. 